\title{
Environmental and health impact assessment for ports in Thailand
}

\section{Chamchan Chanchang $^{1}$, Pornchai Sithisarankul ${ }^{2}$, Thanawat Supanitayanon ${ }^{1}$}

${ }^{1}$ Division of Underwater and Aviation Medicine, Naval Medical Department, Royal Thai Navy, Thailand

${ }^{2}$ Department of Preventive and Social Medicine, Faculty of Medicine, Chulalongkorn University, Thailand

\begin{abstract}
Port development in Thailand is an essential part of the national maritime interest in connection with ship and shore activities. The growth of maritime industry and transportation has led to the expansion of ports' areas and capacity. Each port type causes different environmental impacts. Therefore, the Port Authority of Thailand has set up guidelines on ports' environmental management. This is divided into 3 major phases; namely, planning, construction and operation commencement periods. The Report of Environmental and Health Impact Assessment (EIA, HIA and EHIA) is regarded as the environmental management process in the planning period. It is a key tool to anticipate and prevent any adverse effects that might occur on the environment as well as community health resulting from the project implementation. This measure, in turn, creates advance preparation on both the preventive and problem-solving means before the project gets off the ground.

At present, the majority of new projects on port development have still been in the process of information gathering for EHIA submission. Some cannot start to operate due to their EHIA failure. For example, the Tha-sala port which did not pass EHIA, mainly because emphasis had been focused on adhering to legal regulations without taking into consideration the in-depth analysis of data being conducted by community entities in the area. Thus caused the project to be finally abolished.

Impact assessment on environment and health should be aimed at detailed understanding of the community in each particular area so that effective data of objective achievement in preventing environmental problems could actually be carried out and welcomed by the concerned society.
\end{abstract}

(Int Marit Health 2016; 67, 2: 112-116)

Key words: port, wharf, EIA, HIA, EHIA

\section{INTRODUCTION}

Port is regarded as an important project in the development of maritime economy and national interests with a trend of continuous growth in the future. Pursuant problems in such project development come with impacts on both marine and land environment systems as well as air-pollution, which, in turn, affect neighbouring communities in their health condition and quality of life. The process of environmental and health impact assessment (EIA, EHIA, HIA) needed on the part of the projects' owners is essential to lay down appropriate plans in both preventive and problem-solving aspects before project commencement.
Community participation in the assessment of environmental impacts could create a thorough and precise analysis in the genuine requisites of communities in the area [1]. The evident benefits will eventually lead to the coming acceptance and less impacts in the project.

\section{BACKGROUND KNOWLEDGE}

In 1980, Patrick Mitchell Alderton, Professor in Port Management at World Maritime University defined the meaning of "Port" as "areas for ships berthing, anchoring and being equipped with necessary facilities in dealing with ship-and-shore activities or, precisely, port is a piece of land between ships and shores" [2].

Dr. Thanawat Supanitayanon, Division of Underwater and Aviation Medicine, Naval Medical Department, Royal Thai Navy, Thailand, e-mail: send2wat@hotmail.com 
Contributing factors and structures of a port comprise a geographical area for ship shelter both natural and man-made, with construction of deck, breakwater, dolphin and berthing areas. Each port will have a different number of berths, depending on capital investment and accommodation ability. Ship size is basically measured in terms of gross tonnage which is an index related to a ship's overall internal volume.

Port is categorized as a kind of service industry with functions and activities as stipulated in the document of "Guideline for port-related legislation" of Economic and Social Committee for Asia and Pacific (ESCAP, 1991) [3]. Such functions include the following 3 features:

1. Basic functions in collaboration with legal regulation in facilitating activities, like commodity loading, shelter for ships as well as repair and maintenance facilities.

2. Natural functions like safety provision to both lives and valuables of mooring ships, inclusive of efficient and appropriate environmental protection.

3. Functions associated with the environment of local and political circles which cover the responsibility in acting as government representative in the enforcement of safety standards of ships, crews and pollution controls, including consultation service and development of various facilities, such as, school, hospital, medical facility as well as satisfaction on the part of port personnel and the general public in the community.

Ports can generally be categorized into 5 types according to products and service kinds [2]. This classification indicates various activities in ports in which different environmental impacts can possibly occur as followings:

4. General cargo port: transport of commodities in packages or commodities with tangible shapes which might cause leakage and lead to contaminated substance being leaked into water, especially chemical products.

5. Bulk cargo port: transport of agricultural produce, like, tapioca, corn, soybean and minerals which usually require conveyor in the transportation. This practice gives rise to dust being spread in the air or fell down into water which, in turn, can affect the condition of animals, water plants and various activities nearby.

6. Liquid cargo port: transport of petroleum products, liquid chemicals which are inflammable and volatile. Any leakage will affect environmental air, water, and pose a health risk to people. Therefore, special measures in protection are required.

7. Container port: transport of cargo in containers.

8. Passenger ship port: for travel and tour with facility support for ship passengers.

\section{SITUATION IN THAILAND}

Thailand ports with significant development contribution to the country are mainly run by the government's Ministry of Transport. Location and number of ports are 18 ports for Bangkok, 6 for Lam Chabang, 2 for Phuket and 3 for Songkhla deep sea port [4]. In addition, a great number of ports are scattered along the shore lines of the country; Eastern coast, Southern coast along the Gulf of Thailand and Southern coast along the Andaman sea have 198, 120, 125 ports respectively [5].

Statistics of the Ministry of Transport from January 2015 to December 2015 show that the numbers of cargo ships calling on Bangkok port are 3,241 ships and 11,109 ships at Lam Chabang [4]. These ports help generate high economic values to the country. Thailand Research Fund (TRF) estimated that national benefits derived from sea transport are of the highest value, as high as 6.12 trillion Baht (Approximately 158.3 billion Euro).

\section{ENVIRONMENTAL IMPACTS AND MANAGEMENT METHODS OF THAI PORTS}

Environmental impacts arising out from port activities can occur during construction and operation periods. Factors affecting environmental problems of ports consist of the environmental condition of location, project's objectives, and types of commodities for transport, economic and social conditions of the nearby community.

Environmental problems, mostly found around port and adjacent water surface areas, which causes concern to the community and its inhabitants, is mainly oil spill/leakage. According to the statistics of the Marine Department since 1973 to 2013, oil spill incidents have occurred as many as 184 times with the main causes attributing to illegal discharge of ships before reaching port, leakage from cargo ships, capsized and mishap ships [7].

In 2010, the Port Authority of Thailand has compiled a document on 'Guidelines of Ports' Environmental Management", categorizing problems and environmental management into 3 phrases [8].

1. 'Prior to commencement' period deals with report preparation of environmental impact assessment (EIA) in order to lay out plans to determine preventive measures and problem-solving means well ahead of the project's start. This will create appropriate management, post-complication reduction and unanticipated cost increase. Such procedure is legally obliged and regarded as an essential operation phase.

2. Operating activities during the construction period consist of:

2.1. A dredging phase that involves digging of river/ /sea bed to change its sedimentary condition and /location of sediment disposal, both on-shore and in the water.

2.2. A construction phase that involves wharf construction that can create muddy water sediment, 
physical change of water bed, and impacts on plants, marine life, and noise pollution. Moreover, other construction on the in-land wharves can also cause direction change of waterway on the land surface, thus causing soil erosion affecting plants and marine life. Other factor needed to be taken into consideration is the immigration of labourers and construction workers who will bring about increased garbage and wastewater around lodging areas.

3. Eight issues of environmental problems and safety measures are to be observed during the project operational period, namely:

3.1. Wastewater or water pollution;

3.2. Air pollution from dust, chemical odour and toxic gas;

3.3. Noise pollution;

3.4. Garbage and dangerous waste;

3.5. Problems from dangerous substance;

3.6. Problems in land usage;

3.7. Transport;

3.8. Problems related to on-the-job safety.

\section{ENVIRONMENTAL AND HEALTH IMPACT ASSESSMENTS OF PORT PROJECTS} IN THAILAND

Environmental impact assessments (EIA) refer to the assessment of impacts from any projects or businesses which might have impacts upon the environment, or vice versa, any impacts from the environment to the projects, both positively and negatively, so that measures of preventive control can be worked out before decision is reached upon the project implementation. A concrete compilation of EIA in Thailand has been started since 1975 by the promulgation of the National Environmental Promotion and Quality Maintenance Act, 1975, which stipulated that a National Environment Committee (NEC) be set up under the regulation of Ministry of Science, Technology and Energy. In 1981, ten types of project are required to make EIA report and regarded as the start of EIA presentation in ports. Later, the announcement of Ministry of Natural Resources and Environment in the year 2012 has specified the sizes and types of such projects that need EIA report to be increased to 35 classifications [9].

Report of Environmental and Health Impact Assessments (EHIA) was introduced in the Constitution of the Kingdom of Thailand, year 2007. Part 12 on Community Right, Section 67, Paragraph 2 which stated that any activity or project that might cause a "serious impact on community" in terms of environmental quality, natural resources and health, shall not be carried out without a study and assessment of impacts that might occur to the environmental quality and health of people in the community. Procedure to obtain the opinions of people, both pros and cons, should be sought. This also requires related opinions from the Independent Committee on Environment and Health (ICEH) [10]. Lately, the Ministry of Natural Resources and Environment has issued a decree specifying types, sizes and action methods for 11 types of projects that are required to produce EHIA report, in which, port is named as one such project [11].

Health impact assessments (HIA) refer to the process in the forecast and analysis of impacts, both good and bad, which might be caused from the policy or project that have impacts on the health of people as well as the spread of such impacts upon the people. In Thailand, HIA was started by the time of the Kingdom's Constitution, Section 56 , Paragraph 2, in the year 1997, which stated that people and community have the right to take part in the assessments of projects which might cause serious impact on environment and health condition though HIA is mainly regarded as only a part of the EIA report.

Subsequently, the National Health Commission of Thailand has specified 4 different types of HIA report to be conducted according to the following reasons [12].

1. Regarding EHIA in the format as stipulated in Section 67, Paragraph 2 of the Constitution of the Kingdom of Thailand, year 2007.

2. In case of policy making and implementation of developmental plans.

3. Following people's requests to exercise right per Section 11 of National Health Act, year 2007, in assessing the health impact.

4. In order to conduct HIA to be a process of joint learning within affecting society (Community Health Impact Assessment, CHIA).

Ports are listed as a type of project that requires a report on environmental assessment to be made by the time of submission for approval or permission of the project. Report on the environmental assessment of any port project must be delivered to the Marine Department and Office of Natural Resources and Environmental Policy and Planning for approval prior to the start of operation.

Ports that require EIA report are [9]:

1. Ports for ship size from 500 gross tonnage, or with berth length from $100 \mathrm{~m}$ long, or have total port area from $1000 \mathrm{~m}^{2}$ onward.

2. Ports for cruise and sailing ships with the capacity to accommodate more than 50 ships or $1000 \mathrm{~m}^{2}$ upward. Ports that require EHIA reports are [11]:

1. Ports with the berth length over $300 \mathrm{~m}$, or ports' area over $10,000 \mathrm{~m}^{2}$; excluding port for daily use or tourism purposes.

2. Ports with channel dredging greater than $100,000 \mathrm{~m}^{3}$.

3. Ports where hazardous substances or hazardous wastes considered as Group 1 carcinogen is transhipped in total 
quantity of over 25,000 tons monthly or over 250,000 tons yearly.

Examples of some present ports that have carried out the environmental and health impact assessment (EHIA) are:

- Development project of Mabtaput industry port, phase 3 (public scoping step).

- Port construction project at Chumphon province (public scoping step).

- Berthing port at Ban Klong Rua, Krabi province (public review step).

- Port construction project with support centre for the operation of petroleum exploration and production in the gulf of Thailand, at Tha-sala, Nakhonsithammaraj province (the project was terminated without any comment from the Independent Committee on Environment and Health; ICEH).

- Expansion project of port together with underwater pipeline and the construction of container tanks for additional products from Khao Borya gas depot at Sriracha petroleum depot (responsible authority disapproves the resolution on the report and have it withdrawn).

- Construction project of deep-sea port and land reclamation Stage 1, Satul province (EIA report was approved and additional study is being made to prepare EHIA report.

\section{LESSONS LEARNED FROM THE CASE OF THA-SALA PORT'S EHIA}

An interesting case study of a company's environmental and health impact assessment (EHIA) report is against the community's CHIA report aimed at the learning process of the community. The project is a port construction and support centre for the exploration and production of petroleum in the gulf of Thailand at Tambon Glai, Amphur Tha-sala, Nakhonsithammaraj province.

The project consists of L-shaped berthing pier that stretches out into the sea for approximately 500-m long to serve as a transport point of petroleum and chemical products used in the dredging of petroleum. It includes a breakwater, inlet and outlet waterways, streets and green areas. The reasons given in the selection of Tambon Glai are that the areas are not restricted in any conservation limits, both in-land and sea; no specific values in environment and society as well as most of the landscape are mainly of coconut plantation with scarce inhabitant areas. All these factors would lessen various impacts in comparison to other areas. The project is set to get off the ground in 2012 with 18-month duration [13].

The company started conduct EHIA report in February 2008 by following guidelines and action methods as stipulated in the law. The following points are given significant emphasis, namely, selected target groups within the vicinity of $5 \mathrm{~km}$ distance from the project, including concerned public and government units. The report includes:

- assessment of health impacts by way of screening checklist in accordance with the laid down requisites, then accumulate data from various agencies.

- an attitude survey on 328 families, consultation with community leaders and in-depth interview with possible pros and cons parties, like provincial health unit, fishery office and resorts, are all carried out. The EHIA report of the company does not reflect the genuine data, correct understanding of the areas and the compliance to the real demand of the community $[13,14]$.

Later on, the Tha-sala community initiated a joint meeting of feasibility studies in doing HIA report at the community level (CHIA). This was organised by the National Health Commission in April 2008. The work led to the community's learning which, in turn, built up a good shared decision making. Furthermore, more search on the concerned points was made through questionnaire that was subsequently expanded to other target groups of fishermen in the areas and in the Tha-sala with more than 1.000 fishing boats. The discussion enlarged the thinking of community leaders and made the people realise that they had an important part in the project. They realized that the sea had been rich and wanted to preserve the Tha-sala areas as a food production source. Data were collected from hundreds of community in order to get accurate data and delivered to concerned working units as well as to the unit of HIA data learning of the community at Walailuck University in October 21, 2011 [13].

Comparing to CHIA's data, the company's EHIA report is poor in community involvement of the risk assessment which led to improper information that against community concern. In December 2012, the company announced the termination of the above project after it could not give any satisfactory explanations to the society regarding the problematic processes in doing EHIA.

This incident indicated the increased awareness of people on the subject of environmental impacts arisen from various projects, especially in the community directly affected by the project. This reflected the importance of development in the precise, thorough and well accepted analysis of impacts from the procedure in running EIA and EHIA reports.

\section{SUMMARY AND SUGGESTION}

At present, preparation of EIA and EHIA reports still put emphasis on following the course laid down by legal regulation, the majority part of which is correct and well covered. However, it does not pinpoint the accuracy of data in the context related to the chosen areas, resulting in following conflicts. Knowledge provision on EIA, EHIA, HIA to a broader group of people, including of academics in public health circles, community leaders and those with 
interest in such project, will help create a joint cooperation in creativity and data sharing. Committees appointed to the task of making reports on port's EHIA should include to environmental experts in the area or maritime medicine doctors in the assessment of the project so that more diversified and precise data could be obtained. It is of great important since port projects can cause vast effects to both air and land environment as well as on precious sea resources [15].

In future, the creation of understanding among the people of the community and the importance in recognizing data on the demand of locals must be stressed in order to change any possible conflicts into a chance of developing EIA and EHIA reports which can correctly answer the real and true objectives and lead to a sustainable project development.

\section{REFERENCES}

1. Sithisarankul P. The 4 noble truths of HIA and EIA. Thammasat Medical Journal 2014; 14: 102-106 [online].

2. General knowledge about port and ship. Marine department. [online]. 2006 [cited 2015 Oct 25]. Available from: http://oldweb.md.go.th/ marine_knowledge/e-harbour.php.

3. Guidelines for port-related legislation. Bangkok: United Nations; 1991.

4. Port's data. Statistics of transportation. 2015 [cited 2015 Oct 25]. Available from: www.news.mot. go.th/motc/portal/graph/np/ index5.asp [online].

5. Marine knowledge hub. Marine transportation. 2011 [cited 2016 Mar 17]. Available from: http://www.mkh.in.th/index.php? option $=$ com_content\&view $=$ article\&id $=66 \&$ Itemid $=71$ [online].
6. Jarayabhand P. National maritime interest: situation and suggestion. Bangkok, The Thailand Research Fund, 2007; p. 64.

7. Statistics of marine department. Statistics of transportation. 2015 [cited 2015 Oct 25]. Available from: http://www.news.mot.go.th/ motc/portal/graph/index_md4.html [online].

8. Policy and planning division of Port Authority of Thailand. Guidelines of Ports Environmental Management. 2010 [cited 2015 Oct 25]. Available from: http://www1.port.co.th/pshems/download/\# [online].

9. Regulations of Ministry of national resources and environment. 2012 [cited 2015 Oct 15]. Available from: http://www.ratchakitcha.soc. go.th/DATA/PDF /2555/E/097/1.PDF [online].

10. Health impact assessment co-ordinating unit. EHIA. 2015 [cited 2015 Oct 20]. Available from: http://www.thia.in.th/welcome/ article/6/ [online].

11. Regulations of Ministry of national resources and environment. 2010 [cited 2015 Oct 15]. Available from: http://www.onep.go.th/ eia/index.php?Option=com_content\&view=article\&id=81:law-ehia \&catid=18\& Itemid= 111 [online].

12. Sutipanwihan S. Health impact assessment (HIA) under constitution and related law. Document for HIA conference 2014. 2014 [cited 2015 Oct 15]. Available from: http://hsmi.psu.ac.th/ conference/ upload/forum/HIAconference2014FullDocument.pdf [online].

13. Document analysis of EHIA report for Chevron's port project. Document for HIA case conference. 2012 [cited 2015 Oct 26]. Available from: http://www. thia.in.th/welcome/article_read/138 [online].

14. Bureekul T, Prasertcharoenkul R, Na-Nakorn T et al. Manual of public participation in environmental impact assessment. 2014 [cited 2015 Oct 17]. Available from: http://www.tei.or.th/tai/2014-Book-EIA.pdf [online].

15. Supanitayanon T. Maritime medicine. In: Klaewkla C, Wongwanit $P$, Sujirat A, Supanitayanon T eds. Maritime Medicine Naval Medical Department. Naval Medical Department, Bangkok 2014; 5-15. 